\title{
NUTRITIONAL STATUS OF SCHOOL AGE CHILDREN THROUGH ANTHROPOMETRIC ASSESSMENT IN RURAL AREAS OF HAJIPUR
}

\author{
Jolly¹, Mohammad Ahsan Hussain², Anand Kumar 3 , Abdur Rahman Al Adil ${ }^{4}$, Purnendu Kumar Singh 5 , Bijoy Mukherjee ${ }^{6}$
}

1 Junior Resident, Department of Community Medicine, Katihar Medical College, Katihar, Bihar.

${ }_{2}^{2} J u n i o r$ Resident, Department of Community Medicine, Katihar Medical College, Katihar, Bihar.

3Medical Officer, Urban Primary Health Centre, Purnia.

${ }^{4} J u n i o r$ Resident, Department of Community Medicine, Katihar Medical College, Katihar, Bihar.

${ }_{5}^{5}$ Associate Professor, Department of Community Medicine, Katihar Medical College, Katihar, Bihar.

${ }^{6}$ Professor and HOD, Department of Community Medicine, Katihar Medical College, Katihar, Bihar.

\begin{abstract}
\section{BACKGROUND}

One of the greatest problems in India is undernutrition. Nutrition of primary school children is of paramount importance because the foundation for their lifetime health, strength and intellectual vitality is laid during this period. It is a dynamic period of their physical growth as well as of their mental development. According to National Family Health Survey (2005-2006) in Uttar Pradesh, the prevalence of wasted, stunted and underweight children was $14.8 \%, 56.8 \%$ and $42.4 \%$ respectively.

Aims and Objectives- To assess the nutritional status of the Primary School Children (6-15 years) in rural areas of Hajipur.
\end{abstract}

\section{MATERIALS AND METHODS}

This school based cross-sectional descriptive study was conducted among 500 school children aged 6-15 years using systemic random sampling technique in rural areas of Hajipur of Katihar district, Bihar, which was carried out during January 2016 to December 2016.

\section{RESULTS}

Out of total 500 students, 267 (53.4\%) were boys and 233 (46.6\%) were girls. The overall prevalence of underweight, stunting, wasting was $61.6 \%, 51 \%, 44.6 \%$ respectively. Parent's education and occupation was found to be statistically significant with the nutritional status of the children. Underweight was found to be $52.2 \%$ in joint family and only $9.2 \%$ in nuclear family. The prevalence of anaemia is $40.2 \%$, refractive errors $8 \%$, dental caries $19 \%$, throat infection $15.4 \%$

\section{CONCLUSION}

Most of the school-age children in our study had a poor nutritional status. Interventions such as nutrition education, fortification of food items, effective infection control, and training of public healthcare workers and delivery of integrated programs are recommended.

\section{KEYWORDS}

Undernutrition, School-Going Children, Maternal Education.

HOW TO CITE THIS ARTICLE: Jolly, Hussain MA, Kumar A, et al. Nutritional status of school age children through anthropometric assessment in rural areas of Hajipur. J. Evolution Med. Dent. Sci. 2017;6(93):6730-6734, DOI: 10.14260/jemds/2017/1457

\section{BACKGROUND}

School age is the active growing phase of childhood. ${ }^{1}$ Primary school age is a dynamic period of physical growth as well as of mental development of the child. Research indicates that health problems due to miserable nutritional status in primary school-age children are among the most common causes of low school enrolment, high absenteeism, early dropout and unsatisfactory classroom performance. The present scenario of health and nutritional status of the school-age children in India is very unsatisfactory. According to National Family Health Survey (2005-2006), in India, the prevalence of wasted, stunted and underweight children was 19.8\%, 48\% and 42.5\% respectively; and in Uttar Pradesh,

'Financial or Other Competing Interest': None.

Submission 26-10-2017, Peer Review 22-11-2017,

Acceptance 28-11-2017, Published 11-12-2017.

Corresponding Author:

Dr. Mohammad Ahsan Hussain,

Junior Resident, Department of Community Medicine,

Katihar Medical College, Katihar, Bihar.

E-mail:dr.ahsan09@gmail.com

DOI: $10.14260 /$ jemds $/ 2017 / 1457$ the prevalence of wasted, stunted and underweight children was $14.8 \%, 56.8 \%$ and $42.4 \%$ respectively. $^{2}$

Anthropometry is one of the most useful tool for assessment of the nutritional status of primary school children. There are many anthropometric indicators that describe the nutritional status of children. These are heightfor-age (stunting), weight-for-height (wasting) and weightfor-age (underweight). The Height-for-age index is an indicator of chronic illness and weight-for-height index is an indicator of acute illness. Weight-for-age is a composite index and it takes into account both acute and chronic malnutrition. ${ }^{3}$

In the developing countries like India, various forms of malnutrition affect a large segment of population and both macro and micronutrient deficiencies are of major concern. According to UNICEF data, $90 \%$ of developing world's undernourished children live in Asia and Africa while $40 \%$ of the world's malnourished children live in India. The most recent estimates (1996-2005), in developing world, approximately 146 million children are underweight, out of these 57 million children live in India. ${ }^{4}$

Moreover, schoolchildren are at a high risk of nutritional deficiency and their nutritional status is poorly documented, 
because most of the studies in this country have been conducted on under-five children. We surmise that identifying the contributing factors for undernutrition among schoolchildren is the basic step to set a sustainable and effective nutritional intervention in the study area. Thus, the present study was designed to assess determinants of undernutrition among schoolchildren aged 5-14 years.

\section{MATERIALS AND METHODS}

This school-based cross-sectional survey was conducted among randomly selected school children aged 5-14 years; each alternate student present on the day of examination was then selected for study by systemic random sampling technique. Written and informed consent was obtained from their parents as well as from the principal of the school. The participating students were also informed about the study. The study was conducted over a period of 12 months from January 2016 to December 2016 after the approval of Institutional Ethics Committee (ICE).

Sample size was calculated as $=4 \mathrm{pq} / \mathrm{l} 2$ with $10 \%$ allowable error. Where $\mathrm{p}=50 \%, \mathrm{q}=50 \%$ and $\mathrm{n}=400$. A minimum sample size of 400 school children (5-14 years) was calculated, but 500 students were included in the study for accuracy of the data. All those Above 14 years and below 5 years, who were seriously ill, who were absent on the day of examination, not willing to participate in the study were excluded.

For study purpose, semi-structured and pre-tested questionnaire was used. In the interview schedule, data were obtained regarding the sociodemographic profile of study subjects, like age, sex, type of family, education of mother, education of father, occupation of father and occupation of mother, etc.

Date of birth of the students were taken from school records and the actual age of the child was recorded in years. Their anthropometric measurements including height, weight were also recorded. We have recorded body weight to the nearest $100 \mathrm{~g}$ using a standard balance scale with subjects on barefoot with the help of a weighing machine (bathroom scale) with minimum clothing. Accuracy of the machine as well as zero error was checked every morning before starting the survey.

Height of the children from the floor to the highest point on the head was recorded when the subject was facing directly ahead, barefoot, feet together, arms by the sides of the body. Heels, buttocks and upper back were made to be in contact with the wall when the measurement was made. The height was recorded and rounded off to the nearest $1 \mathrm{~cm}$.

For the assessment of malnutrition, WHO anthropometric classification was used. Based on the age, body weight and height, the children are classified using three categories: 'underweight' (low weight-for-age), 'stunting' (low heightfor-age) or weight for height (wasted).

\section{Data Analysis}

Data collected were entered in Microsoft Office Excel 2007 and analysed. Dependent variable frequencies, percentage, portion were calculated. Chi-square test was used for statistical analysis. The differences were considered as significant at a $p$ value of $<0.05$.

A total of 500 children in the age group of 5-14 years have been included in the study. Out of these, 267 (53.4\%) were boys and $233(46.6 \%)$ were girls. The mean height and weight of girls was found to be lower than boys in the age group 5-10 years and were found to be higher than boys in the age group 11-14 years.

\begin{tabular}{|c|c|c|c|c|c|c|}
\hline $\begin{array}{c}\text { Variables } \\
\text { (Years) }\end{array}$ & Boys & $\mathbf{\%}$ & Girls & $\mathbf{\%}$ & Total & \% \\
\hline $5-6$ & 34 & 12.73 & 28 & 12.02 & 62 & 12.4 \\
\hline $7-8$ & 66 & 24.72 & 80 & 34.33 & 146 & 29.2 \\
\hline $9-10$ & 51 & 19.11 & 48 & 20.60 & 99 & 19.8 \\
\hline $11-12$ & 80 & 29.96 & 59 & 25.32 & 139 & 27.8 \\
\hline $13-14$ & 36 & 13.48 & 18 & 7.73 & 54 & 10.8 \\
\hline Total & $\mathbf{2 6 7}$ & $\mathbf{1 0 0}$ & $\mathbf{2 3 3}$ & $\mathbf{1 0 0}$ & $\mathbf{5 0 0}$ & $\mathbf{1 0 0}$ \\
\hline \multicolumn{6}{|c|}{ Table 1. Distribution of Study Population } \\
\hline
\end{tabular}

\begin{tabular}{|c|c|c|c|c|c|c|c|}
\hline Variables & Boys & $\%$ & Girls & $\%$ & Tota & $\%$ & \\
\hline Normal & 88 & 32.96 & 104 & 44.64 & 192 & 38.4 & \\
\hline $\begin{array}{c}\text { Mild } \\
\text { underweight } \\
\text { (>-1SD to <- } \\
\text { 2SD) }\end{array}$ & 95 & 35.58 & 78 & 33.48 & 173 & 34.6 & $\begin{array}{l}\text { Chi- } \\
\text { square }\end{array}$ \\
\hline $\begin{array}{c}\text { Moderate } \\
\text { underweight } \\
\text { (>-2SD to <- } \\
\text { 3SD) }\end{array}$ & 52 & 19.48 & 38 & 16.39 & 90 & 18 & $\begin{array}{c}=10.942 \\
\text { df }=3 \\
p<0.05\end{array}$ \\
\hline $\begin{array}{c}\text { Severe } \\
\text { underweight } \\
\text { (>-3SD) }\end{array}$ & 32 & 11.98 & 13 & 5.58 & 45 & 9 & \\
\hline Total & 267 & 100 & 233 & 100 & 500 & 100 & \\
\hline \multicolumn{8}{|c|}{ Table 2. Prevalence of Malnutrition } \\
\hline
\end{tabular}

\section{Note}

None of them were found to be obese or overweight.

We observed that 192 (38.4\%) children had normal nutritional level; however, prevalence of moderate malnutrition was $90(18 \%)$ while severe malnutrition was found in 45 (9.0\%) of children and none of them were found to be overweight and obese.

\begin{tabular}{|c|c|c|}
\hline $\begin{array}{c}\text { Age } \\
\text { (Years) }\end{array}$ & $\begin{array}{c}\text { Mean Weight } \\
\text { (kg) Boys }\end{array}$ & $\begin{array}{c}\text { Mean Weight } \\
\text { (kg) Girls }\end{array}$ \\
\hline $5-6$ & 16.59 & 15.81 \\
\hline $7-8$ & 18.81 & 18.43 \\
\hline $9-10$ & 22.77 & 22.60 \\
\hline $11-12$ & 27.74 & 30.68 \\
\hline $13-14$ & 34.24 & 39.22 \\
\hline
\end{tabular}

Table 3. Showing Age-wise Distribution of Mean Weight (in $\mathrm{kg}$ ) among Boys and Girls

\begin{tabular}{|c|c|c|}
\hline $\begin{array}{c}\text { Age } \\
\text { (Years) }\end{array}$ & $\begin{array}{c}\text { Mean Height } \\
\text { (cm) Boys }\end{array}$ & $\begin{array}{c}\text { Mean Height } \\
\text { (cm) Girls }\end{array}$ \\
\hline $5-6$ & 105.82 & 104.93 \\
\hline $7-8$ & 116.18 & 114.59 \\
\hline $9-10$ & 124.68 & 124.64 \\
\hline $11-12$ & 135.52 & 138.87 \\
\hline $13-14$ & 145.35 & 147.69 \\
\hline \multicolumn{2}{|c|}{ Table 4. Showing Age-wise Distribution of Mean Height } \\
(in cm) among Boys and Girls
\end{tabular}




\begin{tabular}{|c|c|c|c|c|}
\hline $\begin{array}{l}\text { Father's } \\
\text { Education }\end{array}$ & $\begin{array}{c}\text { Normal } \\
(\%)\end{array}$ & $\begin{array}{c}\text { Under } \\
\text { Weight } \\
(\%)\end{array}$ & $\begin{array}{l}\text { Total } \\
\text { (\%) }\end{array}$ & \multirow{6}{*}{$\begin{array}{c}\text { Chi-square } \\
=27.921 \\
\mathrm{df}=3 \\
\mathrm{p}<0.05\end{array}$} \\
\hline Illiterate & $89(17.8)$ & $211(42.2)$ & $300(60)$ & \\
\hline $\begin{array}{l}\text { Primary and } \\
\text { middle school }\end{array}$ & $62(12.4)$ & $68(13.6)$ & $130(26)$ & \\
\hline High school & $24(4.8)$ & $21(4.2)$ & $45(9)$ & \\
\hline $\begin{array}{l}\text { Intermediate } \\
\text { and above }\end{array}$ & $17(3.4)$ & $8(1.6)$ & $25(5)$ & \\
\hline Total & $192(38.4)$ & $308(61.6)$ & $500(100)$ & \\
\hline
\end{tabular}

It is seen from the Table 5 that underweight was found to be maximum in those whose fathers were illiterates (42.2\%) followed by those whose fathers were educated up to Primary or Middle School (13.6\%). The prevalence of underweight was found to be $4.2 \%$ and $1.6 \%$ in primary school children whose fathers were educated up to High school and Intermediate respectively. So we can observe that father's education has a role in prevalence of undernutrition. From the table, it can be observed that the relation was found to be statistically significant between father's education and undernutrition.

\begin{tabular}{|c|c|c|c|c|}
\hline $\begin{array}{c}\text { Mother's } \\
\text { Education }\end{array}$ & $\begin{array}{c}\text { Normal } \\
(\%)\end{array}$ & $\begin{array}{c}\text { Under } \\
\text { Weight (\%) }\end{array}$ & $\begin{array}{l}\text { Total } \\
(\%)\end{array}$ & \multirow{6}{*}{$\begin{array}{c}\text { Chi-square } \\
=27.592 \\
\mathrm{df}=3 \\
\mathrm{p}<0.05\end{array}$} \\
\hline Illiterate & $92(29.68)$ & $218(70.32)$ & $310(100)$ & \\
\hline $\begin{array}{c}\text { Primary and } \\
\text { Middle } \\
\text { School }\end{array}$ & $67(50.76)$ & 65 (49.24) & $132(100)$ & \\
\hline \begin{tabular}{|l|} 
High School \\
\end{tabular} & $28(54.90)$ & $23(45.1)$ & \begin{tabular}{|l|}
$51(100)$ \\
\end{tabular} & \\
\hline \begin{tabular}{|c|} 
Intermediate \\
and above
\end{tabular} & $5(62.5)$ & $2(37.5)$ & $7(100)$ & \\
\hline Total & $192(38.4)$ & $308(61.6)$ & $500(100)$ & \\
\hline Table & 2 & 2 & $=2$ & \\
\hline
\end{tabular}

It is observed from Table 6 that underweight in children was found to be maximum in illiterate mothers (218, $70.32 \%$ ) followed by those whose mothers were educated up to Primary and Middle School (49.24\%), High School (45.1\%), Intermediate and Above (35.1\%). So we can observe that as the mother's education status raises prevalence of undernutrition decreases. From this table, it can be observed that the relation between mother's education and child's nutritional status was found to be statistically significant.

\begin{tabular}{|c|c|c|c|c|}
\hline $\begin{array}{c}\text { Father's } \\
\text { Occupation }\end{array}$ & $\begin{array}{c}\text { Normal } \\
(\%)\end{array}$ & $\begin{array}{c}\text { Underweight } \\
\text { (\%) }\end{array}$ & Total & \multirow{6}{*}{$\begin{array}{c}\text { Chi- } \\
\text { square } \\
=13.681 \\
\text { df }=3 \\
\text { p }<0.05\end{array}$} \\
\hline Agriculture & $24(4.8)$ & $29(5.8)$ & $\begin{array}{c}53 \\
(10.6)\end{array}$ & \\
\hline Business & $20(4)$ & $10(2)$ & $30(6)$ & \\
\hline Skilled labour & $67(13.4)$ & $108(21.6)$ & $\begin{array}{l}175 \\
(35)\end{array}$ & \\
\hline $\begin{array}{c}\text { Unskilled } \\
\text { labour }\end{array}$ & $81(16.2)$ & $161(32.2)$ & $\begin{array}{c}242 \\
(48.4)\end{array}$ & \\
\hline Total & $192(38.4)$ & 308 (61.6) & $\begin{array}{c}500 \\
(100)\end{array}$ & \\
\hline
\end{tabular}

It is observed from Table 7 that prevalence of undernutrition in Primary School Children was found to be maximum in those whose fathers were unskilled labourers (161. 32.2\%) followed by skilled labourer (108, 21.6\%), agriculture $(29,5.8 \%)$ and businessman $(10,2 \%)$. From the table, it is also observed that the relation between father's occupation and nutritional status was found to be statistically significant.

\begin{tabular}{|c|c|c|c|c|}
\hline $\begin{array}{c}\text { Mother's } \\
\text { Occupation }\end{array}$ & $\begin{array}{c}\text { Normal } \\
(\%)\end{array}$ & \begin{tabular}{|c|}
$\begin{array}{c}\text { Underweight } \\
(\%)\end{array}$ \\
\end{tabular} & $\begin{array}{c}\text { Total } \\
(\%)\end{array}$ & \multirow{4}{*}{$\begin{array}{c}\text { Chi square } \\
=6.429 \\
\mathrm{df}=1 \\
\mathrm{p}<0.05\end{array}$} \\
\hline $\begin{array}{c}\text { Working } \\
\text { mother }\end{array}$ & $10(21$. & 37 (78.72) & 47 & \\
\hline Housewife & $182(40.17)$ & $271(59.82)$ & $453(100)$ & \\
\hline Total & $192(38.4)$ & $308(61.6)$ & $500(100)$ & \\
\hline
\end{tabular}

Regarding mother's occupation and nutritional status, maximum number of mothers were housewives. It can be observed from Table 8 that out of 47 children of working mothers, $78.72 \%$ students were underweight. Among 453 children of housewives, $59.82 \%$ children were undernourished. The table also reveals the statistically significant relation between mother's occupation and nutritional status.

\begin{tabular}{|c|c|c|c|c|}
\hline $\begin{array}{l}\text { Type of } \\
\text { Family }\end{array}$ & $\begin{array}{c}\text { Normal } \\
(\%)\end{array}$ & $\begin{array}{c}\text { Underweight } \\
\text { (\%) }\end{array}$ & $\begin{array}{c}\text { Total } \\
\text { (\%) }\end{array}$ & \multirow{4}{*}{$\begin{array}{c}\text { Chi square } \\
=130.213 \\
\mathrm{df}=1 \\
\mathrm{p}<0.05\end{array}$} \\
\hline Nuclear & $125(65.10)$ & $47(15.26)$ & $172(34.4)$ & \\
\hline Joint & $67(34.90)$ & $261(84.74)$ & $328(65.6)$ & \\
\hline Total & $192(100)$ & $308(100)$ & $500(100)$ & \\
\hline
\end{tabular}

It is clearly seen from Table 9 that the prevalence of underweight was found to be maximum in joint family (52.2\%) than nuclear family (9.4\%). Results showed statistically significant relation between type of family and primary school children.

\begin{tabular}{|c|c|c|c|}
\hline $\begin{array}{c}\text { Socioeconomic } \\
\text { Status }\end{array}$ & $\begin{array}{c}\text { Normal } \\
\text { (\%) }\end{array}$ & $\begin{array}{c}\text { Under } \\
\text { weight } \\
(\%)\end{array}$ & \multirow{6}{*}{$\begin{array}{c}\text { Chi square } \\
=159.583 \\
\text { df }=3 \\
\mathrm{p}<0.05 \\
\\
\text { nal Status }\end{array}$} \\
\hline Class II & $71(14.2)$ & $6(1.2)$ & \\
\hline Class III & 49 (9.8) & $40(8)$ & \\
\hline Class IV & $44(8.8)$ & 83 (17) & \\
\hline Class V & $28(5.6)$ & $179(35.8)$ & \\
\hline Total & $192(38.8)$ & $308(62)$ & \\
\hline
\end{tabular}

\section{Note}

None of them belonged to Socioeconomic class I.

It is observed from Table 10 that the percentage of undernutrition was found to be maximum in Socioeconomic class V (35.8\%) followed by class IV, III, II i.e. 17\%, 8\%, 1.2\% respectively. Thus, we conclude from the table that significant relation exists between Socioeconomic class and nutritional status. 


\begin{tabular}{|c|c|c|c|c|c|c|}
\hline 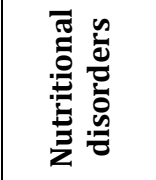 & 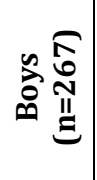 & 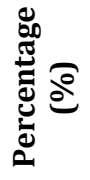 & 芳 & 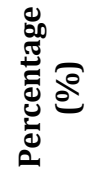 & 풍 & 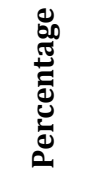 \\
\hline Anaemia & 104 & 20.8 & 97 & 19.4 & 201 & 40.2 \\
\hline $\begin{array}{l}\text { Vitamin A } \\
\text { deficiency }\end{array}$ & 8 & 1.6 & 11 & 2.2 & 19 & 3.8 \\
\hline \begin{tabular}{|l|} 
Vitamin B \\
deficiency \\
\end{tabular} & 18 & 3.6 & 13 & 2.6 & 31 & 6.2 \\
\hline \begin{tabular}{|c} 
Refractive \\
errors
\end{tabular} & 27 & 5.4 & 13 & 2.6 & 40 & 8 \\
\hline $\begin{array}{c}\text { Dental } \\
\text { caries }\end{array}$ & 51 & 10.2 & 44 & 8.8 & 95 & 19 \\
\hline \begin{tabular}{|c|} 
Throat \\
infection
\end{tabular} & 41 & 8.2 & 36 & 7.2 & 77 & 15.4 \\
\hline $\begin{array}{c}\text { Skin } \\
\text { disease }\end{array}$ & 9 & 1.8 & 8 & 1.6 & 17 & 3.4 \\
\hline Total & 258 & 51.6 & 222 & 44.4 & 480 & 96 \\
\hline
\end{tabular}

Regarding Morbidity pattern of children under study, most common types of morbidities were Anaemia (20.8\%), Caries in tooth $(10.2 \%)$ followed by throat infection $(8.2 \%)$; and refractive errors (5.4\%) were more common in boys while Anaemia and dental caries more common in girls (19.4\%, 8.8\% respectively). Vitamin B, Vitamin A, Skin diseases were less common health problems among both (6.2\%, 3.8\%, 3.4\% respectively).

\section{DISCUSSION}

Undernutrition and over-nutrition are the important health problems encountered commonly in school going children. In the present study, we observed a comparatively higher prevalence of undernutrition followed by moderately undernourished $(90,18 \%)$ and severely undernourished $(45$, 9.0\%) which is dissimilar to that reported by G K Mendhi et al from Assam. ${ }^{5}$ Similarly, Bandopadhyay et al from Navinagar, Mumbai reported prevalence for undernutrition was $42.3 \%$. Thus, undernutrition is seen higher among boys than girls. The most probable reason for better results in our study could be a better socioeconomic status of the people. 6

A study by Saxena SC revealed that children of housewives were less malnourished than the children of working women.7 Similar findings were noted in a study by Institute of Nutrition and Food Hygiene, Chinese Academy of Preventive Medicine, Beijing, China which observed that children of non-working mothers were better nourished than children of working mothers. ${ }^{8}$

Prevalence of undernutrition in mothers educated up to intermediate and graduation, up to High school, Primary and middle school, and illiterate mothers were $37.5 \%, 45.1 \%$, $49.24 \%, 70.32 \%$ respectively.

In a study by Sriavastava $\mathrm{A}$ et $\mathrm{al},{ }^{9}$ mother's education was found to be a strong predictor of child nutritional status. Data analysis of National Family Health Survey (NFHS) 1 also showed that mother's education has a strong independent effect on a child's nutritional status even after controlling for the potentially confounding effects of other demographic and socioeconomic variables. 10
These findings were similar to study by Panda $\mathrm{P}$ et al in Ludhiana city ${ }^{11}$ where anaemia was the most common finding at $26 \%$ and second commonest finding was dental caries (23.1\%) followed by refractive errors (5.6\%). Another study by Pandey $\mathrm{S}$ et al in Bhaktapur ${ }^{12}$ from Nepal shows that most common health problem was Ear Problems (Wax, Otitis media \& Otitis Externa; 22.3\%) and next commonest problem was dental caries (13.56\%); this may be due to geographical region as well as examination schedule.

\section{CONCLUSION}

The study concludes that there is still a void in educating school children on hand washing, keeping ears clean, adequate nutrition, and personal hygiene especially brushing technique to prevent dental caries. Also, it has been seen that child nutrition status has a close connection with the mother's education reflecting again the importance of women empowerment and education.

\section{Limitations}

The Study was conducted on Primary School Children who were-

- $\quad$ Of both gender (boys and girls).

- Willing to participate in the study.

- Residing in Hajipur.

The Study Excluded the below-mentioned Primary School Children-

- Above 14 years and below 5 years.

- Who were seriously ill.

- Who were absent on the day of examination.

- Not willing to participate in the study.

\section{REFERENCES}

[1] Nutrition for the school-aged child. Neb Guide Series No.G92-1086-A. 2002; p. 1

[2] International Institute of Population Sciences (IIPS). National Family Health Survey (NFHS-3), Fact sheets for 29 States. Mumbai: International Institute for Population Sciences India, Mumbai 2007.

[3] Bose K, Bisai S, Mukherjee S. Anthropometric characteristics and nutritional status of rural school children. The Internet Journal of Biological Anthropology 2007;2(1):11-7.

[4] Nutritional Anaemia in South Asia. Nutrition in South Asia -a regional profile. F, 1997:75-83.

[5] Medhi GK, Barua A, Mahanta J. Growth and nutritional status of school age children in tea garden workers of Assam. J human Ecol 2006;19(2):83-5.

[6] Bandopadhyay D. A nutrition survey of school children, Navi Nagar, Mumbai. Medical Journal and Forum India 1988;44(1):31-4.

[7] Saxena SC, Saxena P, Gupta SC, et al. A study of protein calorie malnutrition amongst under six children in slum area of Kanpur. Indian J of Community Health 2003;15(2):25-30.

[8] Lü B, Zhai F, Jin S, et al. Impact of maternal occupation on the dietary and nutritional status of preschool children. A case study in 8 provinces of China. Wei Sheng Yan Jiu (Journal of Hygiene Research) 1999;28(1):47-9. 
[9] Srivastava A, Mahmood SE, Srivastava PM, et al. Nutritional status of school age children - a scenario of urban slums in India. Arch Public Health 2012;70(1):8.

[10] Mishra VK, Retherford RD. Women's education can improve child nutrition in India. NFHS Bulletin 2000;15:1-4.
[11] Panda P, Benjamin AI, Singh S, et al. Health status of school children in Ludhiana City. Indian Journal of Community Medicine 2000;25(4):150-5.

[12] Pandey S, Dudani I, Pradhan A, Health profile of school children in Bhaktapur. Kathmandu University Medical Journal 2005;3(11):274-80. 